\title{
Reflections of an Unwitting 'Political Entrepreneur'
}

\author{
ALFRED E. KAHN * \\ Robert Julius Thorne Professor of Political Economy, Emeritus, Cornell University \\ Special Consultant, NERA Economic Consulting
}

\begin{abstract}
By focusing on my role in airline deregulation, Philip Weiser's generous characterization of me as a political entrepreneur slights the large part of my career, expounding and then applying the economics of regulation to New York's public utilities. It fails also to convey the gradualness of my realization, at the $\mathrm{CAB}$, that there was no acceptable half-way house between the thoroughgoing regulation I had inherited and genuine deregulation eighteen months later. Finally, it overlooks the contradiction most 18th century liberals would see between my efforts at the CAB and my conception of the strong antitrust policy that logically accompanies deregulation.
\end{abstract}

\section{Introduction}

I am overwhelmed by this special issue of the Review of Network Economics, and cannot possibly convey the full measure of my gratitude to the friends and collaborators - all of them also mentors - who have organized and participated in its publication.

While immensely gratifying to me, and in some sense objectively correct, however, Professor Weiser's (2008) characterization of me as a "political entrepreneur", presumably bent from the outset on deregulating the airlines, fails to convey the gradualness not merely of the process itself but of my realization that there was no acceptable half-way house between the thoroughly cartelistic regulatory regime I inherited in the spring of 1977 and the legislative triumph of deregulation in the fall of 1978.

The qualified nature of my initial commitment to what we at the time called "regulatory reform" is further reflected in the fact that I initially declined the Chairmanship of the Civil Aeronautics Board (CAB), for two reasons: the first was my own agnosticism about the viability of unregulated competition in an industry arguably prone to destructive competition (Kahn, 1988, Vol. 2, Chapter 5); the second, my lack of interest, at the time of intensified recognition of our national energy problem, in "making it easy for people to jet all over the world" - a sentiment that resonates with especial clarity today: recall that the original OPEC oil export embargo had only a few years previously trebled the price of a barrel of oil on the East Coast, from about $\$ 3.50$ to $\$ 12.00$ a barrel.

Moreover, having come from almost three years as Chairman of a public utility regulatory commission, I was sensitive to the political benefits of regularly scheduled service, particularly made possible in important measure by regulatorily-prescribed crosssubsidization of thin by dense routes, off-peak by peak - making it not merely politically prudent but wise to proceed with liberalizations step-by-cautious step, ending up in

* NERA Economic Consulting, 308 N. Cayuga, Ithaca, NY 14850. E-mail: Alfred.Kahn@nera.com I want to give especial thanks to Timothy Tardiff: it is literally true that I could not have completed this paper without his unfailingly patient and resourceful assistance and support. 
decisions providing open, permissive entry into individual markets, modified only - at the suggestion of Congress - by a modest, explicitly subsidized essential air service program.

For launching me in a public career of regulation and deregulation, I gratefully acknowledge the counsel and support of my former graduate student, Irwin M. Stelzer, who first provided me with the opportunity, in his astonishingly developing economic consultancy, to expound the economic principles, which ended up several years later as the first volume of my Economics of Regulation (Kahn, 1988); then in persuading me that it would be insane for me to follow my initial inclination to turn down New York Governor Wilson's offer of the Chairmanship of the State Public Service Commission - the opportunity of a lifetime, he pointed out, to apply in real life the results of my academic efforts - for all of which I owe him eternal gratitude.

Some three years later, after we at the Civil Aeronautics Board had continued and generalized the Board's initial approval of discount fares, under my predecessor, John Robson, I received a formal complaint from one Dr. Stelzer for having had to pay full fare for a seat next to an unkempt and smelly hippie, who, he surmised, had undoubtedly paid much less than he for his seat.

I responded promptly:

Dear Dr. Stelzer:

I have before me your complaint about your recent experience ... Before taking any action, we are waiting to hear from the hippie"

- a response that apparently did not impair our friendship.

At the New York PSC, I inherited Chuck Zielinski, first assistant, facilitator, disciple, guide and, ultimately and justly, successor as Chairman; and Dennis Rapp, who later played the same role - including that of "bad cop" in the "good cop/bad cop" routine - at the CAB. Among his major - and characteristic - accomplishments behind the scenes there was to bludgeon down from 15 to 8 weeks the slow decision-making process we had inherited - evidently from the Magna Carta - in the landmark case that eventuated in our opening Chicago's Midway Airport to free competition. I will never forget also the many nights he spent months later helping get me established in the White House in my succeeding, Peter Principle-fulfilling role as Advisor to the President on Inflation, while during the daytime continuing his work as Managing Director of the CAB.

At the Board, it was Michael Roach who played the Zielinski role of my closest advisor, giving me the benefit of his far greater experience than mine with airline regulation and firmer conviction about the need for drastic reform. Then there was Darius Gaskins, whom I appointed as Chief Economist, and who later went on as Chairman of the Interstate Commerce Commission to do for trucking what he helped us do at the CAB. I acknowledge also the initial proposal of deregulation by the Ford Administration and the substantial steps taken by the Board under its Ford-appointed Chairman, John Robson, before I came on the scene. To these efforts I brought my own previous explications of the inefficiencies of cartelization - as in my article on cartels and trade associations in the 1968 Encyclopedia of Social Sciences; "The [Oil Industry] Depletion Allowance in the Context of Cartelization," one of my favorite scholarly articles (see Kahn, 1964), and the long sections in the second, institutional volume of my Economics of Regulation describing the absurdity of our governmentally-imposed regulatory cartelizations particularly of trucking. As to the last, I gratefully acknowledge the early instruction of the late Walter Adams - a self-proclaimed anti-Chicagoan and tireless critic of big business who did epochal work in the mid-1950s with a subcommittee of the Senate's Small Business Committee exposing the evils of government cartelization of that industry (see 
U.S. Senate Select Committee on Small Business, 84 ${ }^{\text {th }}$ Congress 2 Session, 1956); our general counsel, Phil Bakes - a gift to us from Senator Kennedy; the Senator himself and his exciting telephone call to me in Albany: "Dr. Kahn? This is Ted Kennedy. I want you to take that job"; and Harvard Law Professor Stephen - now Supreme Court Justice Breyer; the - invisible to me at the time but, I am authoritatively informed, powerful guiding and goading influence of Mary Schuman - now Boies - in the Carter White House; and CAB members, Betsy Bailey, whose appointment Mary Schuman and I had urged upon the President, and the supportive Democratic carry-over Board members Joseph Minnetti and Lee West: I apologize for sounding like a 16-year-old starlet gushingly accepting an Academy Award.

Penultimately, there was the historic moment when I invited Michael Levine, author of pioneering, powerful expositions of the case for deregulation, to join our efforts, responding to his initial discouraging response about all the other attractive prospects on his plate: "Mike, think of it this way: whether or not you accept, we will proceed with [what we, reflecting the tentativeness of our initial efforts, referred to at the time as] regulatory reform; think how you're going to feel if you've not been directly participating?” He promptly accepted and, characteristically, aggressively and creatively assumed leadership of our staff's efforts.

As to the results: to be sure, the 25- to 30-point increase in airline load factors achieved by the unleashing of competitive discounting meant (pace Irwin) increased crowding and discomfort, often severe, sometimes intolerable. But it was precisely the failure of the industry under regulation to offer travellers of modest means a choice of economy over comfort that constituted both the need for deregulation and the essence of its success. The experience wonderfully illustrates the principle that cartelization of a structurally competitive industry - in particular, the prohibition of price competition - sets off all sorts of other forms of cost-inflating competition, substantive and non-substantive, the fatal flaw of which is that it denies customers the choice of low-priced service without those amenities.

If price is prevented from falling to marginal cost ... then, to the extent that competition prevails, it will tend to raise cost to the level of price.

Control entry as well, and the result will be an artificial stimulus to compete by offering larger commissions to travel agents, advertising, denser scheduling, free meals, and bigger seats. The response of the complete regulator, then, is to limit advertising, control scheduling and travel agents' commissions, specify the size of the sandwiches and seats and the charge for in-flight movies. Each time the dike springs a leak, plug it with one of your fingers; just as a dynamic industry will perpetually find ways of opening new holes in the dike, so an ingenious regulator will never run out of regulatory fingers.

And price competition does so much more. It puts severe pressure on managements, which regulation can never duplicate, to improve the efficiency with which they operate, and to hold down the prices they pay for labor and other inputs. And, in contrast with capacity controls, it provides the maximum assurance that the cost savings will, in fact, be passed on to the travelling and shipping public.

The economically efficient way of deciding how much higher-cost service should be provided is to give customers a choice between it and lower price/quality combinations. ... (see Kahn, 1988, pp.28-32 and 208-220).

Worse yet, the congestion was predictable and its simple economic remedy urgently prescribed by me for the Department of Transportation, as they had been previously by Michael Levine: the failure of these government agencies to adopt time-of-day and location-varying congestion pricing, following the unexceptionable principles set forth in 
my Economics of Regulation, bears a heavy responsibility for the chronic, often intolerable, delays plaguing airline passengers in recent years.

Returning then to Professor Weiser's generous characterization of me: first, as to my "political entrepreneurship", there was my initial declining the CAB Chairmanship in the spring of 1977, because it seemed to me bad energy policy - and that was before I became aware also of the huge contribution of jet engine exhaust to global warming. Indeed, recognizing that in the new world telecommuting and teleconferencing would have to substantially displace [observe my recently achieved liberation from one of the irrational rhetorical shibboleths I prescribed upon first assuming the CAB Chairmanship] physical transport, I actually inquired timidly about the possibility of my making a switch with whoever might be named to the chairmanship of the Federal Communications Commission (FCC): "He can't possibly know less than I about the airline industry," I observed, and I had been involved over at least the preceding two decades dealing with the telephone business in one capacity or another (compare McDonald, 2008; Kahn, 1978b). ${ }^{1}$

It was only when, shortly thereafter, the ultimate telephone message, "The President wants to see you" - made it clear that this was where genuine regulatory reform was going to start, I seized the opportunity to "play the Walter Mitty role of a mouse driving that elephant" - with the enormous benefits to the flying public - transient, alas, but for at least a quarter-century - authoritatively documented by Winston and Morrison in the tenor of billons of dollars annually (see Morrison and Winston, 1995; Kahn, 2008, pp.21-25). ${ }^{2}$

I do not suggest that the world owes it to me or to itself to perceive every nuance of my evolving views; but any implication that I came to the CAB, opportunistically and with a preconceived fixed commitment to flat-out economic deregulation, does an injustice to the complexities of the issue itself - including, prominently, my own to-this-day continuing ambivalence about such regulatory policies as the subjection of various other franchised utilities, such as municipal bus, cable TV, or, yes, telecommunication carriers, to the obligation to serve ubiquitously and on a 24 hour basis - and to the evolution of my own conclusion that, so far as airlines were concerned, there was no acceptable half-way house - of "regulatory reform” rather than simple deregulation.

In his recent long memoir, Alan Greenspan summarizes my list, some eight months into the job, of the absurdities forced upon me by the "reform" of airline price competition:

My favorite description of this was by Alfred Kahn, a wisecracking economist from Cornell University [moi?] whom Jimmy Carter made head of the Civil Aeronautics Board and who became known as the Father of Airline Deregulation. Speaking in 1978 on the need for change, Fred

\footnotetext{
${ }^{1}$ So much also for a recent, in other respects highly informative historical account by Michele McDonald, who labels me ${ }^{-}$quite mistakenly ${ }^{-}$as a preconvinced deregulator:

A number of voices had been raised in favor of deregulating the airlines. Among there were a couple of academics who would ultimately make their mark on the industry: A young Yale graduate student named Michael Levine [this reference is entirely correct] and a Cornell professor named Alfred Kahn,

evidently unaware of how genuine the agnosticism with which I ultimately decided to accept the CAB chairmanship. While I had indeed used the regulated airline record as exemplifying the cumulative nature of regulation of a structurally competitive industry ${ }^{-}$repress competition in price and it will extend and show up in all sorts of socially more dubious forms [see note 1 above] ${ }^{-}$I had by no means settled on deregulation as a workable alternative, fully conscious also of the tendency of the industry to destructive competition and the possible threat of unregulated competition also to the familiar imposition on franchisees of such obligations as serving unprofitable markets as a quid pro quo for their legal monopolies.

${ }^{2}$ See also my speech "Route Awards and Airline Scheduling Practices," given to FAA Conference, March 22,1978 , available from the author upon request.
} 
couldn't resist riffing on the thousands of picayune decisions he and the board were called upon to make: "May an air taxi acquire a fifty-seat plane? May a supplemental carrier carry horses from Florida to somewhere in the Northeast? Should we let a scheduled carrier pick up stranded charter customers and carry them on seats that would otherwise be empty, at charter rates? ... May a carrier introduce a special fare for skiers but refund the cost of their ticket if there is no snow? May the employees of two financially affiliated airlines wear similar-looking uniforms?” Then he looked at the congressmen and said, "Is it any wonder that I ask myself every day: Is this action necessary? Is this what my mother raised me to do?” (see Greenspan, 2007)

To this selected list, I add two others of my particular favorites:

- How many facilities on what purported to be an organized tour might the tour operator neglect to inspect on the premises, while still qualifying for free passage?

- $\quad$ Then there was the early evening telephone call, well after office hours, from someone whose name I did not recognize, asking me what had happened to his petition for approval of an arrangement he had made - once again, with an unlicensed or supplemental carrier - to transport a cargo of sheep from some place in Virginia to England. His need for prompt approval, he averred, was urgent because the sheep [I should have been more specific, the ewes] were in heat and being transported for breeding purposes (see Kahn, 1979b).

- hardly the view of a preconverted deregulator, but reflecting six months of experience of trying to "reform" regulation, gradually and partially. Only a few months later, industry leaders themselves either came to the same conclusion or recognized the necessity of adjusting to mine. ${ }^{3}$

President Carter's dedication to deregulation - in this case, of trucking - was further exemplified by an uneasy meeting that I had a few months later with Frank Fitzsimmons, the powerful boss of the Teamster's Union, in which, speaking in my new and not-verycongenial role of Advisor on Inflation to a president he probably held in contempt, I tried to persuade him to comply with our wage guidelines - fully recognizing that the only effective recompense I could offer was the one neither the President nor I was willing to consider: a promise to relent in our efforts to deregulate trucking. (I belatedly acknowledge the yeoman contributions to that legislative accomplishment of Ron Lewis, one of my senior deputies at the White House.) In that sense, we clearly had the last laugh - at the predictable price, however, of having eventually to leave the repression of inflation to Fed Chairman Paul Volcker - also, be it noted, a Carter appointee - whose successful restraints were steadfastly continued by his successor, Mr. Greenspan.

There are other parts of my history as regulator, some clearly compatible, others really inconsistent with the picture of me that Professor Weiser has drawn from my airline experience:

\footnotetext{
${ }^{3}$ I described this development in my May 22, 1978 talk to the American Association of Airport Executives:

“A Funny Thing Happened on the Way to Cincinnati," referring particularly to the "epiphany and miraculous conversion” of Albert Casey, CEO of American Airlines. In contrast, as Professor Robert Solow, then President of American Economic Association, aptly pointed out when introducing my delivery of the Richard Ely lecture at the organization's annual convention, “Delta Airlines was not ready when he was".

In supplementing the historical record, I cannot refrain from observing also that while graciously giving me this credit, Alan Greenspan characterizes deregulation at this point as “the Ford Administration's great unsung achievement”: President Carter, Senator Kennedy and Stephen Breyer receive credit only in a later point (p.82), Senators Howard Cannon and Bob Packwood and Mary Schuman none at all.
} 
- my determined application of the marginal cost pricing principles expounded in my first volume to regulation of electric and telephone services in New York State - proudly detailed by me in a series of articles in Public Utilities Fortnightly (see Kahn, 1978a; Kahn, 1974, in response to “institutionalist's" criticism) - regarded as sufficiently revolutionary at the time to inspire an unsuccessful effort to get me to recuse myself from electric rate proceedings for having "prejudged" that issue;

- my long opposition to AT\&T’s bundling its own customer premises equipment with its franchised monopoly telephone service - refusing to permit attachment of competitively provided equipment - first expressed in a memo I sent in 1956 (as a member of the Senior Staff of the President's Council of Economic Advisors to Arthur Burns, then Chairman), indignantly reacting to an FCC decision sustaining AT\&T's barring the clip-on attachment to the customer's phone of the independently-offered Hushaphone device - prohibited by AT\&T on the ground that it made voice messages unintelligible - ("all the party at the other end has to do,” I observed, “is exclaim 'I can’t understand you!' or, more helpfully, 'take that damned muffling device off your phone"”) a position we generalized two decades later at the New York Commission, with the able assistance of Chuck Zielinski;

- my ambitious, prescient but ignored parting memorandum to AT\&T in 1969, after my several years membership on its National Economic Advisory Council, urging it to abandon the exclusionary practices that ultimately led to its dissolution and instead adopt what I labeled "A Grand Competitive Strategy”; and

- my testimony in Congress in opposition to several "Bell bills" seeking to retain or restore the Bell monopolies.

It has taken some thirty years for my earlier - in no sense original - prognostication about aviation - upon originally declining the CAB Chairmanship - to be vindicated: no industry can have been more catastrophically affected than commercial aviation by $\$ 140$ a barrel crude oil - less so but still radical $\$ 63$ as of this writing. I take some rueful satisfaction in having been prematurely prescient back in 1977 in my reasons for first declining the $\mathrm{CAB}$ chairmanship, even though it will mean an equally dramatic reversal in the accomplishments of deregulation. It was a glorious ride, however bumpy for the drivers, but it is, alas, largely over. How "largely" I will not try to predict, but I have no doubt consumers will continue to be better served under deregulated competition than by a restoration of cartelization under government auspices.

\section{The first skunk at our picnic: My views on antitrust policy}

While most $18^{\text {th }}$ and $20^{\text {th }}$ century liberals alike tend to approve of the role I played in deregulating the airlines, I hope you will find it interesting, and not merely provoking, if I confront the almost certainly far wider spectrum of our opinions on antitrust policy (see Dirlam and Kahn, 1954; McCraw, 1984, pp. 330-333), which, it is commonplace to observe, takes over responsibility for protecting the public when direct regulation is withdrawn. 
To put it simply, my views are more likely to be reflected in the - alas, typically dissenting - opinions of Justices Stevens, Souter, Ginsburg and Breyer than in the - alas, predominating for at least the next several years - Justice Scalia. There! I assume, with regret, that observation will alienate enough of you to qualify your approval of my role in deregulating the airlines and truckers.

As a self-proclaimed $20^{\text {th }}$ century liberal, I have long been an antitrust true believer of the pre-Chicago variety, emphasizing its role as proscription of anti-competitive conduct collusion and exclusion of rivals from a fair opportunity to compete - and - how old fashioned can one get? - the intent that may be inferred from it (see Kahn, 1953, pp. 28-54; Kahn, 1968, pp. 320-325). Any doubts that this was the intention of the 1890 Sherman Act (see Thorelli, 1955) should in my opinion have been put to rest by the 1914 Federal Trade Commission (FTC) Act, with its flat prohibition of "unfair methods of competition".

The last half-century has, in contrast, witnessed the virtual triumph of the opposing, conservative view, rationalized by University of Chicago economists, highly sophisticated liberals of the eighteenth century variety, that the prohibitions of antitrust, and of discrimination in particular, should apply only upon clear demonstration of a genuine threat of injury to consumers (see Hay, 2007).

This issue is clearly exposed in the carefully articulated proposal of the ambitious Digital Age Communications Act (DACA) Project, sponsored by the Progress and Freedom Foundation, in which Professor Weiser was an active participant, explicitly recommending application of the Section 5 FTC Act unfair methods of competition "model" - which accords completely with my own position - but then recommending that the prohibition apply only to practices or behavior that demonstrably "pose a substantial and non-transitory risk to consumer welfare" - a clear victory for the University of Chicago, and probably also representing a consensus view of most respectable economists, for whom it happens also to be a modest Full Employment Act (see Fox, 2006; Lightblau, 2008). ${ }^{4}$

It is difficult to quarrel in principle with the consumer welfare standard implicit in this interpretation of the prohibition, for example, of predation. The trouble is that its application typically involves tortured controversies over whether the typically highly pinpointed responses of the incumbent to a rival's initiative do or do not recover the latter's incremental costs - an essentially regulatory exercise. Consistently with my behavioral conception of the antitrust proscription, I have long ago endorsed the alternative proposal of Professor William J. Baumol that when and if an incumbent carrier does respond with price reductions highly pinpointed at the competitively initiated price reductions or bargains, and the response does induce the withdrawal of the original bargain price, the initiator be required to continue the bargain for some stipulated period of time - say, a year, thereby putting on the successful responding carrier the responsibility for deciding whether its response is compensatory, and ensuring consumers, at least for some specified period of time, the continued benefit of the competition (Kahn, 2006).

More generally, few Western economists would disagree with the proposition that the ultimate goal of economic policy and criterion of its success or failure is whether policy or arrangements in question serve the interests of consumers, in the aggregate. The difficulty from my standpoint, particularly in an era and industry, such as telecommunications,

\footnotetext{
${ }^{4}$ For an explicit confrontation of this issue and exposition and defense of the position I explicate here, see Fox (2006). The issue has recently broken into the daily press with the immediate, open criticism by the three members of the Federal Trade Commission of an ambitious 215-page report of the Justice Department on the proper treatment of business practices that on their face deny other companies a fair opportunity to compete.
} 
subject to radical dynamic change, both technological and institutional, is that the results of an industry's performance under effective competition are largely unpredictable: indeed, it is the essence of the case for leaving choices to be determined by the competitive market. In these circumstances, the central proper role of antitrust is to keep markets open to competition from both outside and inside. In this conception, the proper role of antitrust policy merges with the value of democratic societies in emphasizing the importance of individual enterprises to offer services in competition with one another. There is of course a great deal of romanticism about this professed goal, just as there is about our asserted freedom of consumer choice; but that is why our society places such a high value on the ability of individuals to form their own businesses, to offer their services freely to customers in competition with one another, free not only of government interference but of exclusionary practices by more powerful competitors.

For these reasons, the antitrust laws are not merely instrumental but embody and serve substantive goals and social values. Likewise the value of fair competition is not merely instrumental - to ensure the equation of prices and marginal costs, for example; but it is intimately associated with the ideal of free markets and free enterprise. Even though in principle the winners from any change in market results can compensate the losers and still be better off under any particular policy or arrangement, in fact such arrangements for compensation do not exist, except only highly and indirectly; and society may have every reason to insist that the competition that prevails under any particular arrangement or set of business policies is "fair".

Consistently with this view, and at the cost of further provoking the many of you who applaud my $18^{\text {th }}$ century but not my $20^{\text {th }}$ century liberalism, I am compelled to repeat my long-expressed belief that there is such a phenomenon as predation; that it has occurred in the airline industry among others - to the injury of consumers; that it can be inferred and sufficiently established from a pattern of conduct by incumbents before, during and after the entry and exit of the provocateur-victim (Kahn, 1991, pp. 137-146; Kahn 1999; Kahn 2001; Kahn, 2006). ${ }^{5}$

To return to telecommunications in particular: while recognizing the overwhelming importance of Schumpeterian, intermodal competition in those markets (for the classic statement, see Schumpeter, 1942, Chapters 9 and 10; McCraw, 2007) as protector of the public interest, I suspect I am more uneasy than most of you about the process by which mergers - both intra-and intermodal - have changed the structure of these markets in the direction of a small number of large, multi-platform firms, with AT\&T and Verizon being the two largest wireless carriers ${ }^{6}-$ a concern apparently vindicated by the fact that in the recent spectrum super-auction, numbers 1 and 2 wireless providers Verizon and AT\&T walked off with the lion's share; numbers 3-6 did not even bid (see Hansell, 2008). While, along with most economists (see Baumol and Robyn, 2006), I am a believer in the desirability of slot auctions at airports and for rights to the spectrum, I have long ago expressed concern that the value of a slot at a congested airport will ordinarily be greater to a hub-dominating incumbent than to a would-be challenger - a position, I find it difficult to doubt, clearly reflected in the results of the spectrum super auction conducted this past March.

\footnotetext{
${ }^{5}$ Also, see my proposed application of this rule as a resolution of the network neutrality issue, in Section 4 below.

${ }^{6}$ On a nationwide basis, AT\&T and Verizon served somewhat over half of the wireless subscribers as of the end of 2006. This combined share would increase with Verizon's announced acquisition of Alltel, the fifth largest facilities-based carrier, which served about five percent of subscribers. FCC (2008a, p.17).
} 
The fact is that concentration ratios in telecommunications are moderate; the incursions of video companies such as Comcast and Time Warner into telephony and of telephone and satellite companies into television and the competition of both in the provision of Internet access are genuinely competitive. ${ }^{7}$

Recognizing that it is possible, consistently, to commend my work at the CAB while disagreeing with my antitrust philosophy (on the ground that governmental prohibitions of competition are more absolute than private restraints), I can only observe the congruity in principle with what I did there and recommend here.

Remembering that this special issue was critically inspired by my work at the CAB, which focused on impairments on the competitive process, I would likewise concentrate the thrust of the antitrust law's prohibition on anticompetitive behaviors that interferes with the ability of efficient competitors - incumbents and challengers alike - to compete on the merits of their offerings - that is, on impairments of the competitive process. Accordingly, the key consideration is the nature and inherent tendency of the competitive practices at issue - not the often difficult-to-determine question of whether the particular practices at issue are on balance good or bad for consumers.

The upshot is that I see no need for the retention or installation of direct regulation: vigilant enforcement of antitrust should suffice. But I would insist it be my version of antitrust, not (I surmise) most of yours!

\section{The skeleton in my closet: Regulation of the field price of natural gas, 1968-72}

I cannot conclude this commentary and confessional without alluding to what will surely appear to most of you a most serious violation of my later fully-articulated marginal-cost pricing principles - the leading role that I played in the late 1950s in not only defending federal regulation of the field price of natural gas, but in drafting the two-price regulatory plan that the Federal Power Commission actually adopted. I trust you will appreciate the irony that while, unsurprisingly, I never succeeded in persuading my then-boss, Arthur Burns, of my views, I myself was heavily influenced in them by the leadership role in support of regulation played in Congress by an illustrious University of Chicago refugee Professor of Economics, Senator Paul Douglas.

My esteemed biographer, Tom McCraw, generously treats this experience only briefly as a hangover of my earlier institutionalist's ${ }^{8}$ learning process that eventuated a decade later in publication of my "masterwork”, Economics of Regulation:

\footnotetext{
${ }^{7}$ In its most recent report on competition in the wireless industry, the FCC (2008a, p.6) reported a Herfindahl-Hirschman index of 2,674 for the US wireless market and noted that no single competitor has a dominant share. In the case of high-speed access to the Internet, FCC (2008b, Tables 1 and 2) statistics indicate that mobile wireless has made substantial inroads into the former cable modem/digital subscriber line duopoly - as of the middle of 2007, mobile wireless accounted for 35 percent of high-speed lines (over $200 \mathrm{kps}$ in at least one direction) and 13 percent of advanced service lines (over $200 \mathrm{kps}$ in both direction,) ${ }^{8}$ His account reminds me that I thought of myself as an institutionalist in my late teens ${ }^{-}$highly skeptical of the assumptions and tenets of neo-classical economics, inheriting that mantle from my mentor, Myron W. Watkins, who had himself been a student of Thorstein Veblen. Although my later discovery of the merits of marginalism placed me in conflict with other self-described institutionalists (see, for example, Kahn, 1974), I hope one day to revisit that literature, particularly in light of my current nagging concerns about "The Threat of Latter-Day ‘Progressives’ to an Authentically Liberal Economic Policy” (Kahn, 2008).
} 
as a scholar steeped in institutionalist methods, Kahn enjoyed certain advantages. In the real world, neither oil nor gas was priced solely through the interaction of supply and demand. Instead, the prices of both were influenced by regulation. Oil was "prorationed" to market demand by the policies of state and federal agencies. It was also subject to a series of laws designed to help certain parts of the industry: schemes ranging from depletion allowances and other tax advantages to oil import quotas. By itself, natural gas also was regulated; it came under the purview of the Federal Power Commission, which engaged in a constant struggle to rationalize its pricing. Just at the time Kahn became interested in the subject, the FPC seemed to be failing in this job. As James Landis, in his Report to the President-Elect of 1960, reminded his readers, the FPC "represents the outstanding example in the federal government of the breakdown of the administrative process." The point was not lost on one reader at least.

Kahn knew that if he were going to do serious work on the regulation of oil and gas, he must master every relevant tool of economic analysis. To be sure, some of these tools belonged to institutional economics. But even more essential, he must learn to use better the methods of neoclassical microeconomics. His re-search into the pricing mechanisms of oil and gas had to be based on the theory of price. At this point in his career, Kahn began the final stage of his intellectual odyssey.

...He continued to study the natural gas issue, as he immersed himself in the vast multidisciplinary literature of regulation and started intensive work on his new book. As he later recalled, "My sense of the economics of all this [pricing of natural gas] didn't really get straight until I wrote my Economics of Regulation.” By 1967, Kahn had begun to chart the course of his masterwork ... In 1970, the first volume of his great book appears in print ... (see McCraw, 1984, pp.234-235)

The facts as I saw them were: that in their search for oil, the major oil companies had discovered huge reservoirs of natural gas - much of it physically associated with and providing the lifting energy that brought the oil explosively to the surface, others in pure gas reservoirs, unassociated with oil. Most of the former gas was simply burned off - so that, I was assured, someone flying over an oil field in the middle of the night could read a newspaper by its light; the non-associated gas wells simply capped for lack of a market the development of which awaited the arrival of long-distance gas transmission lines. This later, adventitious development of a huge market for that gas naturally occasioned intense competition among gas pipeline ventures for long-term contracts committing those reserves, which were prerequisites of FPC certification and cost-plus regulation.

My conception - hardly original - was that the "old” gas, already discovered and, for want of a market, either capped or flared on-site after driving up the oil with which it was associated, had a zero marginal cost; that permitting its price to soar, as it was in the process of doing, to the full marginal cost of "new" gas conferred something like pure economic rent on its owners (I made a similar argument some years later with respect to the pricing of DSL by means of line sharing), which could be expropriated without uneconomically discouraging new supply and - reflecting my youthful exposure to Henry George's Progress and Poverty and my $20^{\text {th }}$ century political liberalism - should be. In addition I cited two other reasons for feeling that the unregulated field price might exceed even long-run marginal costs: the high concentration of supply of uncommitted reserves, a prerequisite of pipeline certification, and the fact that those certifications were in effect "licenses to print money" - an anticipation of the later-articulated Averch and Johnson distortion under rate base/rate of return regulation (see Averch and Johnson, 1962; Wellisz, 1963).

My successful testimony not only articulated the rationale for FPC regulation of the field price but also proposed the two-price plan that the Commission likewise adopted - a lower historical-book cost for gas already discovered, a higher price intended to reflect the costs of gas discovered and developed henceforward - both of them involving (only) plausible allocations of cost between (regulated) gas and (unregulated) liquids. 
I tell this story additionally because that testimony probably was, paradoxically and by coincidence, the critical factor leading to my odyssey as a political entrepreneur: I was appointed to the New York Commission chairmanship evidently upon the recommendation of my predecessor, Joseph C. Swidler, who had previously been Chairman of the very Federal Power Commission that had adopted my rationale and plan for regulating natural gas.

In any event, I felt compelled in my Volume I testimonial to marginal cost pricing principles to reconcile them with the position I had taken with respect to natural gas some fifteen years previously. That reconciliation appears in a few slightly labored footnotes easy to find via the excellent index (which I prepared).

Whatever the merits of my rationalization of the two-price system of regulation, the simple economic efficiency preached in my Volume I requires that all supplies of a standardized product, whatever the differing circumstances of its discovery and production, be priced at the marginal cost of supply necessary to clear the market. The field price of natural gas, thus regulated, it cannot be doubted, fell over time increasingly short of that level: the result was the necessity for ever-tighter direct rationing, the responsibility for which, by a sort of poetic justice, I was forced to take over once I assumed the Chairmanship of the New York Commission.

\section{$4 \quad$ Dropping the final shoe - Swiftly and lightly}

By now the interested reader will surely have glanced at his watch wondering when I was going to get around to the inevitable subject of network neutrality - and how long that was going to take. Be reassured: much too much has already been said on this subject, fuzzily and repeatedly. I challenge myself to reduce my wavering views to a few bare propositions.

- To induce efficient behavior, the prices confronting buyers and sellers should reflect the marginal costs (causally) associated with - incurred or saved - by current transactions.

- The rapidity of technological and commercial changes in telecommunications and the huge investments required to exploit them preclude anything even remotely approximating traditional cost-of-service regulation, whether of aggregate revenues or of the prices of individual services.

- $\quad$ Each of the principal carriers is subject to competitive pressure to offer the full range of services from its several platforms.

- When, however, something like two multi-platform companies have come, arguably, to dominate these several markets, in very large measure by mergers of previous competitors, one cannot be fully satisfied that competition will sufficiently protect consumers or independent profferors of content. That "arguably" is a weasel word: the FCC has released large portions of the spectrum precisely to encourage competitive wireless offerers. It is not encouraging, however, that, as I have already pointed out, among the providers of wireless telephony only AT\&T and Verizon actually bid in the recent large spectrum auction, emerging with the lion's share (see Hansell, 2008). 
- It is emphatically not discriminatory - or in itself undesirable - for internet access providers to vary their charges depending on the demands that the several users impose on their networks, or for different guaranteed speeds of delivery, at different prices, reflecting those varying requirements. On the contrary, that is the result that would be produced by effective, consumer-protecting competition.

- Moreover, genuine price discrimination may be the only way of recovering the huge investments required to exploit the new technologies, and are objectionable only if they are anti-competitive.

- The only interventions clearly justified, at this time, would be antitrust-like in character - discriminations against providers of content competitive with the offerings of the carriers themselves, or their affiliates - and refusals to interconnect with one another for the transmission of competitor-originating content.

- $\quad$ But the version of antitrust that I urgently recommend - consistently with my position over the last more than half century - would flatly condemn such discriminations against competitors, or refusals to deal with them, without the University of Chicago-mandated demonstration of injury to customers, such as the enduring 5\% price differential required in the Department of Justice's merger guidelines.

- I will have to save for a later day the formidable task of deciding where these last two propositions leave me in deciding the merits of Thomas Hazlett's denunciations of the FCC's recent condemnation of Comcast for assertedly discriminating against certain bandwidth-intensive applications competitive with its own (see Hazlett, 2008). I strongly suspect, however, that this case will have illustrated the likely differences in our views about the role and interpretation of antitrust that I have already labeled "the first skunk at our picnic": I would be inclined to condemn any such discriminations per se, as my sole endorsement of a net-neutrality mandate.

\section{$5 \quad$ References}

Averch, H. and L. Johnson (1962) "Behavior of the Firm under Regulation Constraint," American Economic Review 52: 1052-1069.

Baumol, W.J. and D. Robyn (2006) "Toward an Evolutionary Regime for Spectrum Governance - Licensing or Unrestricted Policy?” AEI-Brookings Joint Center for Regulatory Studies.

Dirlam, J.A. and Kahn, A.E. (1954) Fair Competition - The Law and Economics of Antitrust Policy. Cornell University Press: Ithaca, New York.

Federal Communications (2008a) Implementation of Section 6002(b) of the Omnibus Budget Reconciliation Act of 1993, Annual Report and Analysis of Market Conditions With Respect to Commercial Mobile Services, WT Docket 07-71, Twelfth Report, February 4. 
Federal Communications Commission (2008b) High-Speed Services for Internet Access: Status as of June 30, 2007. Industry Analysis and Technology Division, Wireline Competition Bureau, March.

Fox, E.M. (2006) Chapter 11 "Abuse of Dominance and Monopolisation: How to Protect Competition Without Protecting Competitors," Chapter 11 in European Competition Law Annual 2005: What Is An Abuse of A Dominant Position? in Ehlermann and Atanasiu (ed.), Hart Publishing: Oxford, England.

Greenspan, A. (2007) The Age of Turbulence - Adventures in a New World. The Penguin Press: New York.

Hansell, S. (2008) "Verizon and AT\&T Win Big in Auction of Spectrum," New York Times, March 21, 2008, p. C3.

Hay, G.A. (2007) “The Quiet Revolution in U.S. Antitrust Law,” Cornell Law School Research Paper No. 07-023.

Hazlett, T. (2008) "FCC should Leave Net Neutrality to Anti-trust Courts,” Financial Times, September $30 . \quad$ http://www.ft.com/cms/s/0/bac78ca4-8ee8-11dd-946c0000779fd18c.html

Kahn, A.E. (1958) “Standards for Antitrust Policy,” Harvard Law Review, 67: 28-54.

Kahn, A.E. (1964) “The Depletion Allowance in the Context of Cartelization,” American Economic Review, 54: 286-314.

Kahn, A.E. (1968) "Cartels and Trade Associations,” in David L. Sills (ed.), International Encyclopedia of the Social Sciences, The Macmillan Company \& The Free Press, 2, pp. 320-325.

Kahn, A.E. (1974) "Economic Theory as a Guideline for Government Intervention and Control: Comment," in Warren J. Samuels (ed.), Methodology of Economic Thought, Transaction Publishers, Edison, NJ, pp. 380-386.

Kahn, A.E. (1978a) “An Economist at Work at Utility Rate Regulation,” Public Utilities Fortnightly, January 5, 19 and February 2.

Kahn, A.E. (1978b) “The Changing Environment of International Air Commerce," Presentation before a symposium, Georgetown University, Washington, D.C., May 4, 1978; reproduced in Air Law (Netherlands), 3(3).

Kahn, A.E. (1979a) “Applications of Economics to an Imperfect World," American Economic Review, 69: 1-13.

Kahn, A.E. (1979b) Speech to the New York Society of Security Analysts, February, available from the CAB files in Cornell University Archives.

Kahn, A.E. (1988) The Economics of Regulation: Principles and Institutions, Vol. 1: Economic Principles, Vol. 2: Institutional Issues. John Wiley \& Sons: New York, 1970-71, reprinted by The MIT Press: Cambridge, Massachusetts.

Kahn, A.E. (1991) “Thinking about Predation - A Personal Diary,” in Review of Industrial Organization, 6: 137-146.

Kahn, A.E. (1999) “Comments on Exclusionary Airline Pricing,” Journal of Air Transport Management, 5: 1-12. 
Kahn, A.E. (2001) "Whom the Gods Would Destroy, or How Not to Deregulate," AEIBrookings Joint Center for Regulatory Studies, May 2001, Chapter 6.

Kahn, A.E. (2006) “Telecommunications: The Transition from Regulation to Antitrust," Journal on Telecommunications \& High Technology Law, 5: 159-188.

Kahn, A.E. (2008) "The Threat of Latter-Day 'Progressives' to an Authentically Liberal Economic Policy,” published by the AEI Center for Regulatory and Markets Studies, pp. 21-25.

Lightblau, E. (2008) “Antitrust Document Exposes Rift,” New York Times, September 9, p. C1.

McCraw, T.K. (1984) Prophets of Regulation: Charles Francis Adams, Louis D. Brandeis, James M. Landis, Alfred E. Kahn. Belknap Press of Harvard University Press: Cambridge, MA.

McCraw, T.K. (2007) Prophet of Innovation: Joseph Schumpeter and Creative Destruction. Harvard University Press: Cambridge, MA.

McDonald, M. (2008) "Changed forever - The Transition from Total Government Control of the Airline Industry to Open Competition has been a Wild Ride that Some Enjoyed and Some Did Not," Air Transport World 40th Anniversary Issue. http://www.atwonline.com/channels/airlineFocus/article.html?articleID=1159

Morrison, S.A. and C. Winston (1995) The Evolution of the Airline Industry. Brookings Institution Press: Washington, D.C.

Schumpeter, J.A. (1952) Capitalism, Socialism and Democracy. Harper \& Row: New York, NY.

Thorelli, H.B. (1955) The Federal Antitrust Policy, Origination of an American Tradition. Baltimore, Johns Hopkins Press.

U.S. Senate Select Committee on Small Business, 84th Congress 2 Session “Competition, Regulation and the Public Interest in the Motor Carrier Industry, Senate Report No. 1693, Washington, March 19, 1956.

Weiser, P.J., “Alfred Kahn As A Case Study of A Political Entrepreneur,” The Review of Network Economics, 7: 603-615.

Wellisz, S.H. (1963) "Regulation of Natural Gas Pipeline Companies: An Economic Analysis,” Journal of Political Economy, VXXI: 30-43. 